\title{
IDENTIFIKASI PATOTIPE GLOBODERA ROSTOCHIENSIS MENGGUNAKAN KLON DIFERENSIAL
}

\author{
Lisnawita1, Supramana², \& Gede Suastika² $^{2}$ \\ 'Program Studi Agroekoteknologi, Fakultas Pertanian, Universitas Sumatera Utara \\ Jl. Prof. A. Sofyan No.3, Kampus USU, Padang Bulan, Medan, Sumatera Utara 20155 \\ ${ }^{2}$ Departemen Proteksi Tanaman, Fakultas Pertanian, Institut Pertanian Bogor \\ Jl. Kamper, Kampus IPB, Darmaga, Bogor 16680 \\ E-mail: itamuis@yahoo.com atau lisnawita.usu@ac.id
}

\begin{abstract}
Identification of Globodera rostochiensis using differential clones. Potato cyst nematode, Globodera rostochiensis, is a relatively new pathogen in Indonesia that becomes a constraint to potato production. To manage the parasite effectively, it is very important to identify the pathotype of G. rostochiensis populations. Therefore, this research was carried out to identify G. rostochiensis pathotypes. Four G. rostochiensis samples, consisting of three samples from East Java and one sample from Central Java, were identified using a set of differential clones. The result showed that G. rostochiensis samples from East Java were new pathotype, whereas the sample from Central Java was Rol pathotype.
\end{abstract}

Key words: differential clone, Globodera rostochiensis, Indonesia, pathotype

\section{ABSTRAK}

Identifikasi patotipe Globodera rostochiensis menggunakan klon diferensial. Nematoda sista kentang (NSK) G.lobodera rostochiensis adalah patogen yang relatif baru di Indonesia yang dapat menjadi faktor penghambat produksi kentang. Pengendalian NSK yang efektif memerlukan informasi tentang patotipe G. rostochiensis yang ada. Oleh karena itu dilakukan penelitian yang bertujuan untuk mengidentifikasi patotipe G. rostochiensis. Empat sampel G. rostochiensis, yang terdiri dari tiga sampel dari Jawa Timur dan satu sampel dari Jawa Tengah, diidentifikasi dengan menggunakan set klon diferensial. Hasil penelitian menunjukkan bahwa sampel Jawa Timur merupakan patotipe baru, sedangkan sampel Jawa Tengah merupakan patotipe Ro1.

Kata kunci : Globodera rostochiensis, Indonesia, klon diferensial, patotipe

\section{PENDAHULUAN}

Nematoda sista kentang (NSK) Globodera spp. merupakan patogen penting pada pertanaman kentang yang telah menyebar luas di dunia dan menyebabkan kerusakan dan kehilangan hasil yang cukup besar (Evans \& Turner, 1998). Di Indonesia, NSK telah tersebar di Jawa Timur, Jawa Tengah dan Jawa Barat (Lisnawita et al., 2013). Identifikasi spesies secara molekuler dengan menggunakan Polymerase Chain Reaction (PCR) terhadap 11 isolat NSK asal Indonesia menunjukkan bahwa NSK asal Jawa Timur dan Jawa Barat adalah G. rostochiensis, sedangkan NSK asal Jawa Tengah adalah G. rostochiensis dan G. pallida (Lisnawita et al., 2012).

Kedua spesies NSK mempunyai beberapa patotipe yang berbeda (Kort et al., 1977). Patotipe NSK dikarakterisasi berdasarkan kemampuannya untuk bermultiplikasi pada klon-klon diferensial (Dunnett,
1961). Di Eropa terdapat lima patotipe G. rostochiensis dan tiga patotipe G. pallida (Kort et al., 1977), sedangkan di Amerika Selatan terdapat empat patotipe G. rostochiensis dan enam patotipe G. pallida (Canto Saenz \& Scurrah, 1977). Patotipe yang ada di Indonesia, terutama patotipe G. rostochiensis, belum diketahui, padahal bibit kentang yang ditanam di Indonesia diimpor dari berbagai negara sehingga meningkatkan peluang masuknya berbagai patotipe NSK.

Pengetahuan tentang patotipe yang tersebar diperlukan untuk perancangan metode pengendalian NSK yang tepat. Penelitian ini bertujuan untuk mengetahui patotipe G. rostochiensis asal Indonesia dengan menggunakan set klon diferensial.

\section{METODE PENELITIAN}

Sampel G. rostochiensis. Empat sampel $G$. rostochiensis, masing-masing tiga sampel dari Jawa 
Timur (S1, S2 dan S3) dan satu sampel dari Jawa Tengah (S4) digunakan pada percobaan ini. Keempat sampel yang digunakan diambil dari tanaman kentang varietas Granola yang terinfeksi NSK di lapang.

Perbanyakan G. rostochiensis. G. rostochiensis diperbanyak dari sista tunggal (single cyst) yang diinokulasikan pada tanaman kentang rentan yaitu varietas Desiree hasil kultur jaringan (koleksi Laboratorium Biomolekuler dan Seluler Tanaman, Pusat Penelitian Sumberdaya Hayati dan Bioteknologi, IPB). Perbanyakan kentang dilakukan dengan menyubkultur stek buku tunggal pada media Murashige dan Skoog (MS0) pH 5,8 dengan tambahan sukrosa 30\% dan bubuk agar 8 g. Perbanyakan NSK dilakukan dengan menggunakan metode yang dikembangkan oleh Foot (1977) dengan sedikit modifikasi. Pot plastik bening dengan diameter $9 \mathrm{~cm}$ dan tinggi $15 \mathrm{~cm}$ disterilisasi permukaan dengan $1 \%$ sodium hipoklorit selama 30 menit, kemudian dibilas dengan air steril sebanyak dua kali. Pot kemudian diisi dengan media tanah steril dan pasir steril $(1: 1, \mathrm{v} / \mathrm{v})$. Selanjutnya pot ditempatkan di Laboratorium Nematologi Tumbuhan, Departemen Proteksi Tanaman, Fakultas Pertanian, IPB pada temperatur $18^{\circ} \mathrm{C}$ (Lisnawita et al., 2010). Tanaman dipelihara selama tiga sampai empat bulan yang diperkirakan mencakup 3-4 siklus hidup NSK (Lisnawita, 2007), hingga diperoleh jumlah sista yang cukup untuk pengujian (Gambar 1). Sista diekstrak dari tanah dan akar menggunakan metode Sheperd (1985).

Perbanyakan Set Klon Diferensial. Set klon diferensial yang digunakan adalah set klon diferensial komersil yang merupakan pengganti dari set klon diferensial klasik (Kort et al., 1977), terdiri atas varietas Maritta, Saturna, KTT 60.12.19, ODV 32731, S. verrnei hibrid 62.33.3 dan AM 78.3778 (Tabel 1). Set klon diferensial ini diperoleh dari Plant Reserch Institute, Wageningen, The Netherland). Perbanyakan set klon diferensial dilakukan secara in-vitro dengan

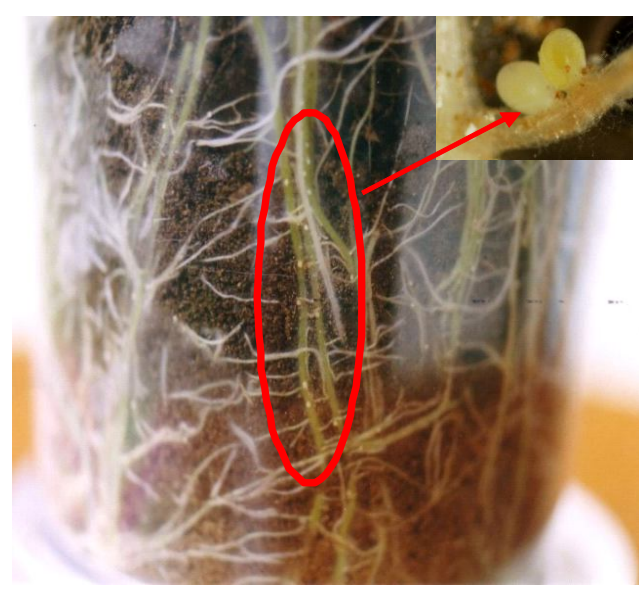

Gambar 1. Sista dan betina Globodera rostochiensis (lingkaran merah).

Tabel 1. Klon diferensial kentang untuk penentuan patotipe nematoda sista kentang G. rostochiensis

\begin{tabular}{lccccc}
\hline & \multicolumn{5}{c}{ Patotipe } \\
\cline { 2 - 6 } \multicolumn{1}{c}{ Klon diferensial $^{\text {a }}$ komersil } & \multicolumn{7}{c}{ (Canto Saenz \& de Scurrah, 1977; Kort et al. 1997) } & Ra1 & Rb1 & Ra2 & Ra3 \\
& Ro1 & Ro4 & Ro2 & Ro3 & Ro5 \\
\hline Maritta (Solanum tuberosum tuberosum) & + & + & + & + & + \\
Saturna (S.t.andigena CPC 1673) & - & - & + & + & + \\
KTT 60.21.19 (S.kurtzianum hib.60.21.19) & - & + & - & + & + \\
ODV 32731 (S.vernei hib. 58.1642/4) & - & + & - & - & + \\
S.vernei hib. 62.33.3 (S.vernei hib. 62.33.3) & - & + & - & - & + \\
AM 78.3778 (S.vernei hib. 65.346/19) & - & - & - & - & - \\
\hline
\end{tabular}

$+=\mathrm{Pf} / \mathrm{Pi}>1,-=\mathrm{Pf} / \mathrm{Pi} \leq 1, \mathrm{Pf}=$ jumlah sista akhir, dan $\mathrm{Pi}=$ jumlah sista awal. ${ }^{\text {a) }}$ Tetua dari masing-masing klon diferensial yang digunakan ditulis dalam tanda kurung. 
menggunakan mata tunas pada media Murashige dan Skoog (MS0) pH 5,8 dengan tambahan sukrosa 30\% dan bubuk agar $8 \mathrm{~g}$. Setelah dihasilkan 2-3 buku, buku tunggal distek dan disubkultur pada media baru. Setelah berumur 2 minggu plantlet diaklimatisasi dengan memindahkannya ke dalam pot plastik (diameter $5 \mathrm{~cm}$ dan tinggi $9 \mathrm{~cm}$ ) berisi tanah steril dan arang sekam steril $(1: 1, \mathrm{v} / \mathrm{v})$. Dua minggu kemudian tanaman dipindah ke polibeg ukuran $30 \mathrm{~cm}$ x $30 \mathrm{~cm}$ berisi tanah steril dan pasir steril $(1: 1, \mathrm{v}: \mathrm{v})$. Tanaman dipupuk dengan $3 \mathrm{~g} \mathrm{NPK}$ (15:15:15) dan pupuk daun cair ( $2 \mathrm{ml} / \mathrm{l})$ seminggu sekali dan jika diperlukan disemprot dengan insektisida.

Pengujian Patotipe G. rostochiensis. Pengujian dilakukan di rumah kasa di Cipelang, Cijeruk dengan ketinggian tempat $1.250 \mathrm{~m}$ d.p.l. Inokulasi dilakukan setelah tanaman diferensial dalam polibeg berumur dua minggu dengan meletakkan satu kantong kasa berukuran $2 \times 2 \mathrm{~cm}^{2}$ berisi 25 sista dengan jarak $0,5 \mathrm{~cm}$ dari pinggir polibeg dan $6 \mathrm{~cm}$ dari dasar polibeg (Foot, 1977; Franco, 1979). Varietas-varietas pembanding hasil perbanyakan kultur jaringan yaitu Desiree sebagai kontrol rentan dan dua varietas komersil yang paling banyak ditanam petani di Indonesia (Granola dan Atlantik) diinokulasi dengan sista dengan cara yang sama.

Pengamatan dilakukan pada 12 minggu setelah inokulasi dengan membongkar tanaman secara hati-hati. Sista diekstrak dari tanah menggunakan metode penyaringan (Shepherd, 1985), sedangkan sista pada akar diperoleh setelah akar dicuci dan dikeringanginkan. Kemampuan reproduksi (Pf/Pi) tiap sampel dihitung dengan membandingkan jumlah sista akhir (Pf) dengan jumlah sista $(\mathrm{Pi})$.

\section{HASIL DAN PEMBAHASAN}

Keempat sampel G. rostochiensis mampu bereproduksi baik pada ketiga varietas pembanding dengan jumlah sista 28 sampai 489 (Pf/Pi berkisar dari 1,12 sampai 19,59) (Tabel 2). Sebaliknya reproduksi keempat sampel pada varietas diferensial bervariasi. Semua sampel bereproduksi baik pada Maritta, tetapi tidak mampu berkembang pada Saturna, KTT 60.21.19. ODV 32731 dan $S$. Vernei hib. 62.33.3. Sampel S1, S2, dan S3 asal Jawa Timur berkembang baik pada klon AM 78.3778 (S. vernei hib. 65.346/19) sedangkan S4 asal Jawa Tengah tidak mampu bereproduksi. Spektrum virulensi ketiga sampel Jawa Timur berbeda dari deskripsi patotipe menurut Kort et al. (1977) dan Canto Saenz \& de Scurrah (1977) sehingga ketiganya merupakan patotipe NSK baru. Sementara itu, sampel S4 termasuk ke dalam patotipe Ro1 yang umum teridentifikasi di seluruh dunia.

Granola dan Atlantik adalah dua varietas yang paling banyak ditanam di Indonesia. Granola dilaporkan resisten terhadap G. rostochiensis patotipe Ro1 dan

Tabel 2. Reproduksi empat sampel G. rostochiensis pada varietas kentang kontrol dan klon diferensial serta pengelompokan patotipenya

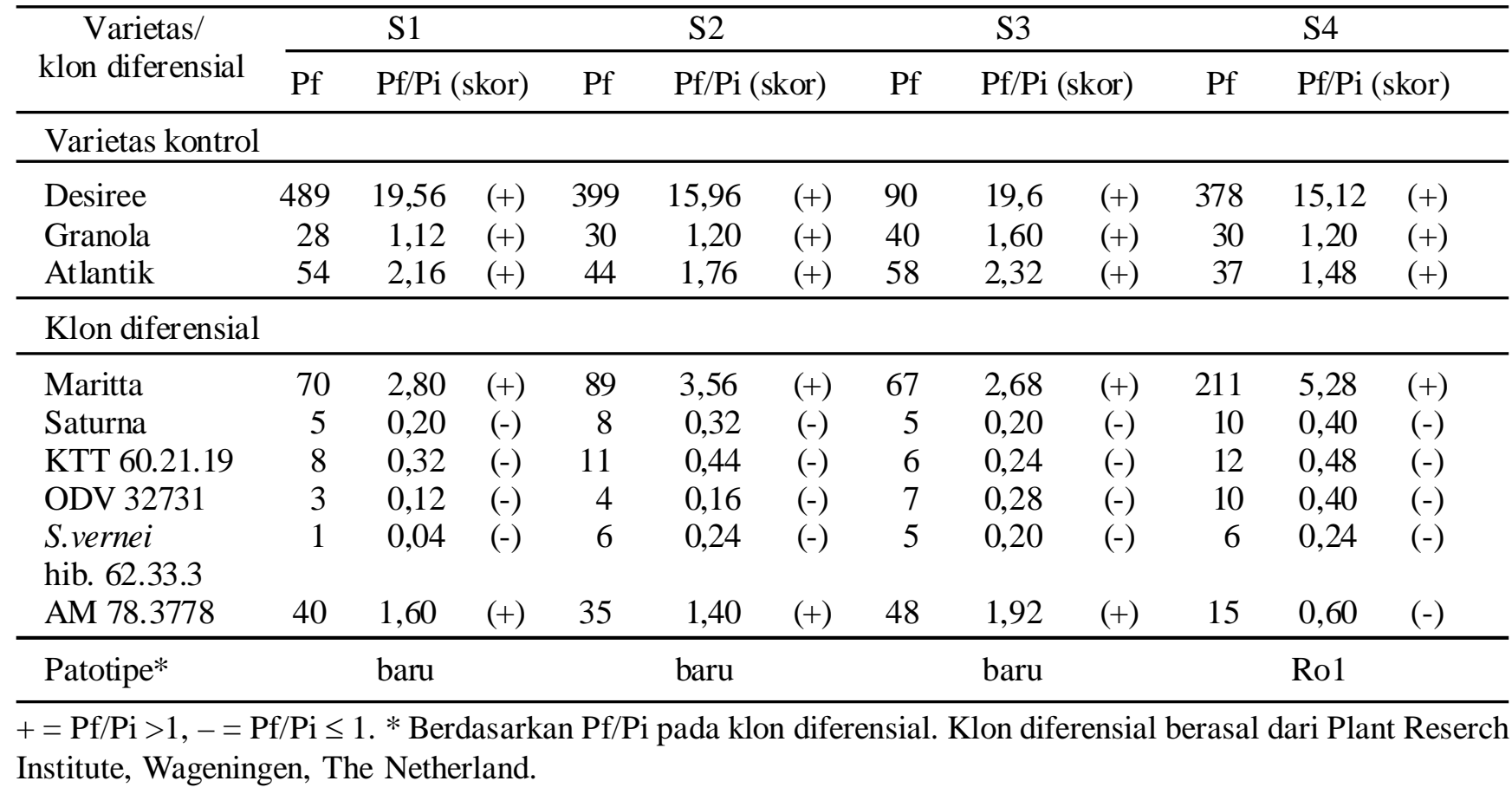


Ro4, sedangkan Atlantik resisten terhadap patotipe Ro1 (Joosten, 1991). Akan tetapi hasil penelitian ini dan penelitian sebelumnya oleh Lisnawita (2007) menunjukkan bahwa kedua varietas dapat terinfeksi oleh isolat-isolat NSK di Indonesia. Bahkan di beberapa lokasi pertanaman di Kota Batu, Jawa Timur, tanaman kentang yang terinfeksi NSK dapat mati pada umur kurang dari satu bulan (Lisnawita, 2007).

Timbulnya patotipe NSK baru di Jawa Timur diduga kuat erat hubungannya dengan 1) praktek penanaman kentang secara terus menerus, dan 2) impor bibit kentang dari berbagai negara. Penanaman kentang di Jawa Timur yang dilakukan dalam skala luas dan sepanjang tahun dapat meningkatkan daya adaptasi NSK pada Granola dan Atlantik yang sebelumnya dilaporkan resisten, sehingga menimbulkan patotipe baru dan ledakan populasi. Terbawanya patotipe-patotipe baru melalui bibit kentang impor dapat meningkatkan peluang terjadinya perkawinan antar patotipe sehingga timbul patotipe baru yang lebih ganas. Terjadi tidaknya perkawinan seksual antar patotipe masih perlu diteliti lebih lanjut karena biologi NSK tropis belum banyak diketahui.

Ditemukannya patotipe baru pada penelitian ini menjadi informasi penting mengingat NSK merupakan salah satu patogen penting yang dapat menjadi faktor pembatas produksi kentang di Indonesia. Jika tidak segera dicari metode pengendalian yang tepat, antara lain penanaman varietas kentang resisten, tanaman perangkap, ataupun rotasi tanaman (SASA, 2010), maka penyebaran NSK patotipe baru dapat semakin meluas seiring dengan penyebaran bibit kentang yang terinfeksi NSK ke daerah-daerah pertanaman kentang lain di Indonesia. Hasil penelitian ini merupakan laporan pertama tentang patotipe G. rostochiensis sampel Jawa Timur dan Jawa Tengah di Indonesia. Pengujian patotipe baru dilakukan pada tiga sampel Jawa Timur dan satu sampel Jawa Tengah dan masih terbatas pada spesies G. rostochiensis, sehingga perlu dilakukan pengujian sampel G. rostochiensis dari daerah lain termasuk sampel G. pallida.

\section{SIMPULAN}

Identifikasi patotipe dengan menggunakan set klon diferensial komersil menunjukkan bahwa ketiga sampel G. rostochiensis Jawa Timur (S1, S2, dan S3) merupakan patotipe baru, karena dapat bereproduksi dengan baik (Pf/Pi>1) pada klon diferensial AM 78.3778 (S. vernei hib. 65.346/19). Sementara itu, sampel Jawa Tengah (S4) tergolong patotipe Ro1.

\section{SANWACANA}

Penulis mengucapkan terima kasih yang sebesar-besarnya kepada Prof. Dr. G.A. Wattimena dan Prof. Dr. Ir. Meity Suradji Sinaga, M.Sc dari Institut Pertanian Bogor atas bimbingannya. Terima kasih juga disampaikan kepada Dr. Richard Janssen dari Plant Research Institute, Wageningen, The Netherland atas pemberian set klon kentang differensial.

\section{DAFTAR PUSTAKA}

Canto Saenz M \& de Scurrah MM. 1977. Races of the potato cyst nematode in the Andean Region and a new system of classification. Nematologica 23: 340-349.

Dunnett JM. 1961. Inheritance of resistance to potatoroot eelworm in breeding line stemming from Solanum multidissectum Hawkes. Res. Scottish Breed Stn 39-46.

Evans K \& Turner JT. 1998. The origins, global distribution and biology of potato cyst nematodes (Globodera rostochiensis Woll. and Globodera pallida Stone.). Pp. 7-26 In: Marks RJ \& Brodie BB. Potato Cyst Nematode-Biology, Distribution and Control. CAB International, Wallingford.

Foot MA. 1977. Laboratory rearing of potato cyst nematode : a method suitable for pathotyping and biological studies. New Zealand. J. Zool 4: 183186.

Franco J. 1979. Effect of temperature on hatching and multiplication of potato cyst nematodes. Nematologica 25: 237-244.

Joosten A. 1991. Genetisch lijst voor Aardappelrassen. Postbus 32, 6700 AA, Wageningen.

Kort J, Ross H, Rumpenhorst HJ, \& Stone AR. 1977. An international scheme for identifying and classifying pathotypes of potato cyst-nematodes Globodera rostochiensis and G. pallida. Nematologica 23: 333-339.

Lisnawita. 2007. Identifikasi, Kajian Biologi, Evaluasi Ketahanan dan Kisaran Inang Nematoda Sista kentang (Globodera spp.) Indonesia. (Disertasi). Institut Pertanian Bogor. 
Lisnawita, Sinaga MS, Supramana, \& Suastika G. 2010. Pengaruh temperatur terhadap perkembangan nematoda sista kentang (Globodera spp.) Indonesia. JHPTT 10(1): 29-34.

Lisnawita, Supramana, \& Suastika G. 2012. Identification of potato cyst nematode in Indonesia by polymerase chain reaction. APDN 7: 133-135.

Lisnawita, Supramana, Suastika G, \& Sinaga MS. 2013. Survei sebaran nematoda sista kentang (Globodera spp.) Indonesia. Pp. 346-352 In : Abdul Rauf, Rahmawaty, Kardhinata EH, Razali \& Irmansyah $\mathrm{T}$, eds. Prosiding Seminar Nasional : Peranan Pers pada Pembangunan Pertanian Berwawasan Lingkungan Mendukung Kedaulatan Pangan Berkelanjutan, Medan, 21 Februari 2013.
SASA. 2010. Control of Potato Cyst Nematodes. Official Control Programme for Sampled Units Recorded as Infested. Guidance for Growers and Landowners. The Scottish Government.

Shepherd AM. 1985. Extraction and Estimation of Cyst Nematodes. Pp. 31-49. In : Southey JF. Laboratory Methods for Work with Plant and Soil Nematodes. Ministry of Agriculture, Fisheries \& Food, London. 